\title{
IAMJ
}

INTERNATIONAL

AYURVEDIC

MEDICAL JOURNAL

\section{PREPARATION OF SAINDHAVADI EYE DROPS: AN AYURVEDIC FORMULATION FOR COMPUTER VISION SYNDROME}

\author{
Vipul Shukla ${ }^{1}$, B. Mukhopadhyay ${ }^{2}$ \\ Junior Resident, Dept., of Shalakya Tantra, FOA IMS, BHU, Varanasi, Uttar Pradesh, India \\ HOD \& Professor, Dept., of Shalakya Tantra, FOA IMS, BHU, Varanasi, Uttar Pradesh, India
}

Corresponding Author: vipulshukla145@gmail.com

\section{https://doi.org/10.46607/iamj0308102020}

(Published online: October 2020)

Open Access

(C) International Ayurvedic Medical Journal, India 2020

Article Received:04/09/2020 - Peer Reviewed:27/09/2020 - Accepted for Publication:29/09/2020

Check for updates

\begin{abstract}
Eyes hold a unique position among all the sense organs. Eyes are the most valuable gift of God to the living beings. Primary importance has been given for the protection of eyes by ancient Indian scholar because without eyes whole world is full of darkness. Acharya Vagbhata says that as long as there is desire for living, so long all efforts should be made always by men to protect the eyes; because for the blind man, night and day are the same; all the things of this world are useless though he might have plenty of money. In this present time, the human lifestyle has been radically changed. When the human race evolved, hunting was very crucial for survival; hence, they were focused for distant vision works that could allow the man to hunt. As the passage of time, science become more developed more and more vehicle develop for livelihood. These days, no longer he requires hunting in the forests. Rather, he has to track the internet on computer in a closed compartment. With over 560 million internet users, India is the second largest online market ${ }^{1}$ in the world, ranked only behind China. By 2021 , there will be over 600 million internet users in India. But in modern system of medicine there is no permanent cure except temporary relieve by artificial tears. Ayurveda is good treatment of the choice.
\end{abstract}

Keywords: Computer Vision Syndrome, Saindhavadi Eyedrop Arka Kalpana 


\section{INTRODUCTION}

Computers are now a fundamental part of our day life today, in the $21^{\text {st }}$ century, where we are living in a highly refined environment; computer is one of the popular developed technologies which are used currently by the children, the young and the old. Most of the people are sitting in front of the computer for longer hours, which is a highly vision challenging job. The advancement in computer science has bring about an enormous change in our lives that we can't imagine life without computer Before the involution of computers, office work had mixed up with various activities including typing, filing, reading, and writing. These activities have need of variety of changes in posture and vision; provide a natural "break" from the prior activity. But now a day's typing writing and reading has been done on a computer without change in posture. The transformation from working in the open to working on paper has been gradual and not very stressful for our visual system. But the shift from papers to computers has been very rapid and strong. Eye could not adapt to the new demands put on it to work at near in face of computers for extensive hours and in extremely tense environments According to national institute of occupational safety and health (NIOSH), CVS affects some $90 \%$ of the people who spent three hours or more a day on a computer. Computer user's vision related problems are the most frequently reported health-related problems occurring in over $70 \%$ of computer users. ${ }^{2}$ they have concluded that CVS is a vision disorder that has been described as the number one occupational hazard of 21 st century. Previous studies have estimated that the prevalence of CVS ranges between 64 and $90 \%$ among computer users. ${ }^{3}$ It has been estimated that nearly 60 million people suffer from CVS globally and about one million new cases occurs each year ${ }^{4}$

According to modern medical science, artificial tear drops are useful in Computer Vision Syndrome. The use of artificial tear drops can reduce the effects of dry eye in CVS. But these artificial tear drops have their own limitations and No counteractive measures for the prevention and cure of Computer Vision syndrome. In modern system of medicine except using ocular surface lubricants, computer glasses, and counseling for judicious computer use ${ }^{1}$. As there is no satisfactory treatment available for computer vision syndrome, Ayurveda, the ancient science of life can be of great help by its preventive and therapeutic principals. Alternative system of medicine like Ayurveda be a good option for improve or to check the pathology of the computer vision syndrome. In Ayurveda there is no description of computer vision syndrome, but it can be an AnuktaVyadhi as describe by Acharya charak. Some of ocular symptoms of CVS can be co-relate with Suskakshipaka as describe by Acharya Sushruta and Astanghridya in the treatment of Shuskakshipaka Acharya Sushruta has described use of Saindhav, Daruhridra, Shunthi and Matulung.

Eyedrop (Aschyotan) is the simplest and most convenient method of topical application. Application in form of eye drops makes the drug available for immediate use. Composition of the Saindhavadi eyedrop have potent activity to prevent the sign and symptoms of Computer Vision Syndrome.

\section{Materials and Method}

\section{Ingredients of the formulation}

Shunthi, Daruhridra, Saindhav Lavan, Matulung

Shunthi

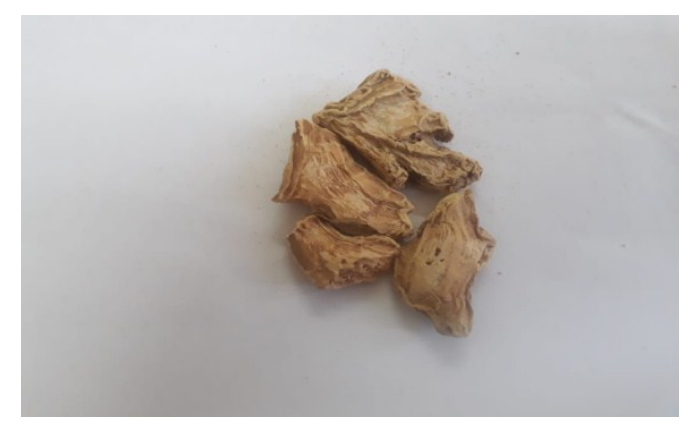

Botanical Name ${ }^{5}$

Zingiber officinale Roscoe

Zingiber - $\quad$ Derived from Shrungaber

Officinale - Sold in shops or used as medicine

Family - Zingiberaceae

Kula - Haridra kula 


\section{Rasa Panchak}

\begin{tabular}{|l|l|l|}
\hline Rasa Panchak & Ardraka & Shunthi \\
\hline Rasa & Katu Tikta, Madhura, Napitta krut (Ashtanga Hridaya) & Katu Pittalam (Kaiyadeva nighantu) \\
\hline Guna & Ruksha, Teekshna & Laghu, Snighdha \\
\hline Vipaka & Ushna & Ushna \\
\hline Karma & Madhura & Madhura \\
\hline Doshgnatha & Bhedani, Deepani & $\begin{array}{l}\text { Amavatagni, Ruchya, Pachani, Viban- } \\
\text { danuth, Vrushya, Swarya }\end{array}$ \\
\hline
\end{tabular}

\section{Daruhridra}

Ayurvedic pharmacological profile ${ }^{6}$

Rasa : Tikta, kashaya
Guna : Ruksha, laghu
Virya : Ushna
Vipaka : Katu

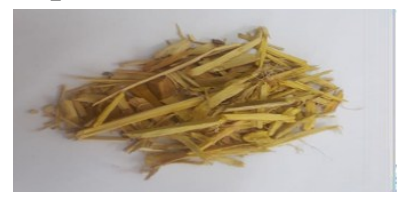

Pharmacology- Hypoglycaemic, anti-cancer, gastroirritant, antifatigue, anticoagulant, antipyretic, local anesthetic, antiprotozoal, anti-TB, anti-bacterial, antitumour, hypotensive, anti-inflammatory, antitrachoma, CNS depressant. Its water extract is called as Rasanjana, used in eye disorders with infection and inflammation. Application of berberine to chronic trachoma patients by intra-conjunctival injection proved highly effective

Actions and Uses (Karma) - Netrya (Conducive to Eye), Aksidosahara (Eye Diseases), KaphabhisyandaNasana (Ocular Inflammation), Vranaropana (Wound-Healing), Shophahara (Anti-Inflammatory).

Saindhav Lavan-Saindhav Lavana or rock salt is considered paramount among all salts. It is advocated for daily use as per Ayurveda. Its properties, usage and health benefits are relatively special from regular salt. it is available from mines of Punjab. it is of two varieties

1 Shweta saindhav - (white in colour)

2.Rakta saindhav - (red in colour)

\section{Chemical composition}

Sodium chloride is the major ingredient making upto $98 \%$ it contains many useful minerals and elements. It also contains iodine lithium, magnesium, phosphorus, potassium, chromium, manganese, iron zinc, strontium, etc.

Qualities, effect on Doshas

Rasa-Lavan, somewhat sweet taste,
Virya-Sheeta

Guna - Laghu unctuous,

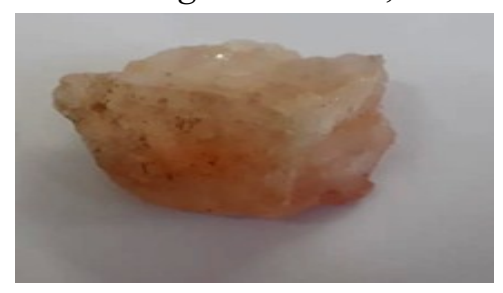

Effect on Tridosha- lavan usually increases Pitta, but Saindhav lavana being sheeta virya it helps to balance Pitta. Because of its salt taste it balances Vata and it help to relieve chest congestion due to sputum accumulation, because it also relieves Kapha. Hence it is one of the rare ayurvedic substance that balances all the three Dosha as per Charaka, it is one of those ingredients, that can be taken on a daily basis, (Pathya),Chakshushya ${ }_{-}^{7}$ good for eye, helps to relieve infection, Avidahi- ( unlike regular salts),

\section{Matulung}

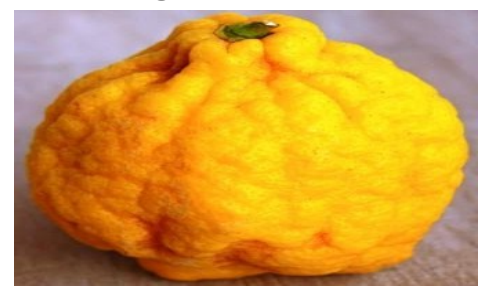

Botanical Name - CitrusmedicaLinn., Family - Rutaceae

\section{Medicinal Properties}

Citron Fruit Medicinal Properties:

Rasa (Taste) - Amla (sour), Madhura;Guna- Laghu, Snigdha; Vipaka-Amla; Virya-Ushna;

Effect on Tridosha-Balances Vata and Kapha Dosha 


\section{Collection and Authentication of raw drugs}

The above-mentioned drugs were collected from Gola Dina Nath Varanasi. The drug identification and analysis were done at Department of Dravyaguna and Department of Rasashastra of Faculty of Ayurveda IMS BHU. Saindhavadi eyedrop were formed in Department of Rasa Shastra and analytical study were done in Department of Medicinal Chemistry in Faculty of Ayurveda IMS BHU

\section{Saindhavadi Eye Drop:}

\section{Apparatus required for distillation ${ }^{8}$}

Distillation is the process by which liquid is vaporized and recollected by cooling and condensing the vapor. The apparatus required for distillation are as follows.

1. Boiler (Heating mantle) - which provides heat and maintain the heat.

2. Vessel, in which vapours are produced by heating the liquid up to its boiling point.

3. Condenser - This function as a cooling device of vapours either by circulation of water or air at atmospheric temperature.

4. Receiver - It is used for the collection of the condensed liquid.

\section{Method of preparation}

Saindhavadi eye drops were prepared by using different parts of medicinally important plant such as $D a$ ruhridra (stem), Shunthi (rhizome), Matulung (Dry fruit), Saindhav Lavan in equal quantity of 200 grams each. The above-mentioned plant materials were taken and made into coarse powder (particles passed through 40- mesh) and soaked overnight in 10 parts of water. Next morning, the soaked drugs were subjected for the distillation process. The vapours are condensed and collected in a receiver. In the beginning, the vapours consist of only steam and may not contain the essential principles of the drugs. It should therefore be discarded. The last portion also may not contain therapeutically essential substance and should be discarded. The final product was in the form of drops, aqueous distillate, sterilized by autoclaving followed by U.V. radiation for $30 \mathrm{~min}$ and stored in $10 \mathrm{ml}$ previously sterilized plastic screw capped airtight container. $\mathrm{pH}$ was maintained continuously by phosphate buffer during preparation (adding isotonic phosphate buffer viz. $0.16 \mathrm{~g}$. of monobasic Sodium phosphate and $0.76 \mathrm{~g}$ of dibasic Sodium phosphate.

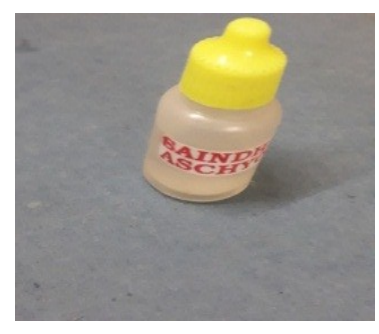

\section{Precautions to be taken ${ }^{9}$}

1. The drugs should be in coarse powder form.

2. The coarse powdered drugs should be soaked in water and then should be subjected to the distillation process.

\section{Duration of preparation- 3 Hours}

Test of Arka $^{10}$

Arka is a suspension of the distillate in water which should be clear and transparent. Colour according to the nature of the drugs used and smell of the predominant drug. When Arka is filled in different Patra, the Colour of Arka should be similar to Shankha, Kundan and moon rays.

The following parameters were studied:

1.Colour, 2. Odour, 3. pH, 4. Clarity test, 5. Sterility Test,

1.Colour the prepared solution of Saindhavadi eye drop was colourless

2.Odour the prepared solution of Saindhavadi eye drop was specific odour

\section{Determination of $\mathbf{P H}$ value:}

Material and Methods: Material- Sample of Eyedrop, Chemical - Distilled water, Equipment ELICO pH meter, conical flask, Filter Paper and funnel

Method: $10 \mathrm{ml}$ of Saindhavadi yoga Eye Drop was taken in a beaker. PH meter was Standardized with the buffer solution of known pH i.e.7. The electrode was rinsed with distilled water and introduced into the test solution taken in a beaker. $\mathrm{pH}$ value of solution was read as per the indicator of the meter.

Result: The pH of Saindhavadi Eye Drop was found 6.7 . 
4.Clarity Test Ophthalmic solution must be free from foreign particles and this is generally accomplished by filtration. The filtration process also helps to achieve clarity of solution.

Method: The ophthalmic solution was centrifuged at $5000 \mathrm{rpm}$ for $30 \mathrm{~min}$. after that solution was filtered with Whatman filter paper

Result: The Saindhavadi eye drop was found free from foreign particles.

5.Sterilization of Eye Drop: $10 \mathrm{ml}$ with aqueous distillate, sterilized by autoclaving followed by U.V. Radiation for $30 \mathrm{~min}$. and stored in $10 \mathrm{ml}$ previously sterilized plastic screw capped airtight container. $\mathrm{pH}$ was maintained 6.7 continuously by phosphate buffer during preparation. ${ }^{10}$ Distillate solution was centrifuged and Autoclaved. The Sterility test of prepared solution was carried at Microbiology Department of IMS BHU. Standard precaution were followed to prepare the sterile inoculums and then distillate solution was inoculated on Blood agar i.e. Enriched medium and sabouraud dextrose agar. To test its Sterility, the Plates were inoculated and incubated at $370 \mathrm{c}$ overnight and examined the next day.

Result: The Saindhavadi eyedrop was found free from microbial organisms

\section{DISCUSSION}

The finished product, Saindhavadi eye drops was colourless and liquid in consistency which establishes the optimum presentation of Arka preparation. The specific odour and taste of Arka is attributed to the ingredients used for its preparation. Computer Vision Syndrome is the most common vision related Problem of the present era. In modern System of Medicine there is no Curative aspect of CVS except artificial eyedrop. Artificial eyedrop have their no own side effect due to presence of preservative but fresh prepared eyedrop have no preservative related side effect. Arka Kalpana is explained in an Ayurvedic literature named Arka Prakasha, where it has been believed that Arka is the most potent among Kalka, Churna, Swarasa, Kashaya, Phanta, Hima. Its shelf life is longer than other Kalpanas like Swarasa, Kwatha etc. This Kalpana is easy to order in the patients compared to $\mathrm{An}$ - jana, Prakshalana etc. Arka is Laghupaki, Vyavayi, Vikasi and thus work quickly on the eye there by gives immediate results. Arka Kalpana acquires highest position in obtaining the potentially active volatile oils as the condensation takes place during the process of distillation.

\section{CONCLUSION}

$A r k a$ is a suspension of the distillate in water having slight turbidity and colour according to the nature of the drugs used and smell of the predominant drug. Arka Kalpana is having more dominance over the other kalpanas, which is having more shelf life, easy to prepare and administer. Arka preparation is also used as eye drops in various eye diseases according to Ayurvedic classics. Hence more practical move toward must be included in the field of manufacture and even by introduction of modern pharmaceutical sector the effectiveness of the medicinal formulations is boosted.

\section{REFERENCES}

1. https:// www. Statistia. Com/ statistics/272438/genderdistribution-of- internet-users-in-India

2. Torrey J (2003). Understanding Computer Vision Syndrome. Employ. Relat. Today 30 (1):45- 51.

3. Hayes JR, Sheedy JE, Stelmack J A, Heany CA (2007). Computer use, symptoms and quality of life. Optomvis. sci.84 (8): 738-744

4. Sen A, Richardson S (2007). A study of computer related upper limb discomfort and computer vision syndrome J. Hum. Ergol (Tokyo) 36 (2):45-50.

5. Thomson M, Al-Qattan KK, Al-Sawan SM, Alnaqeeb MA, Khan I, Ali M, The use of Ginger (Zingiber officinale Rosc.) as a potential anti-inflammatory and antithrombotic agent.

6. Altman RD, Marcussen KC, Effects of a ginger extract on knee pain in patients of osteoarthritis. Arthritis Rehum, 2001; 44(11): 2531-2538.

7. Dr. Anant Ram Sharma. Sushruta Samhita Of Maharshi Sushrut Sutrasthan Varanasi: Chukhambha Surbharati Prakashan; Reprint 2010.verse No 46/314

8. Dr. Anant Ram Sharma. Sushruta Samhita Of Maharshi Sushrut Uttartantra Varanasi: Chukhambha Surbharati Prakashan; Reprint 2010.verse No 50/24 
9. Late Dr. G. K. Garde. Sartha Vagbhat Sutrasthan Varanasi: Chukhambha Surbharati Prakashana; Reprint 2009. Verse No11/22.

10. Sahu. Applicability and Preparation of Arkakalpana in Ayurvedic pharmaceutical industry- A current trend. World Journal of Pharmaceutical Research. 2017; 6(6):1331.

\section{Source of Support: Nil}

\section{Conflict of Interest: None Declared}

How to cite this URL: Vipul Shukla \& B. Mukhopadhyay: Preparation of Saindhavadi Eye Drops: An Ayurvedic Formulation For Computer Vision Syndrome. International Ayurvedic Medical Journal \{online\} 2020 \{cited October, 2020\} Available from: http://www.iamj.in/posts/images/upload/4587_4592.pdf 